\title{
Polaromonas naphthalenivorans sp. nov., a naphthalene-degrading bacterium from naphthalene-contaminated sediment
}

Correspondence

Eugene L. Madsen

elm3@cornell.edu

\author{
Che Ok Jeon, Woojun Park, William C. Ghiorse and Eugene L. Madsen
}

Department of Microbiology, Cornell University, Ithaca, NY 14853-8101, USA

\begin{abstract}
Strain $C J 2^{\top}$, capable of growth on naphthalene as a sole carbon and energy source, was isolated from coal-tar-contaminated freshwater sediment. The Gram reaction of strain $\mathrm{CJ}{ }^{\top}$ was negative. The cells were non-spore-forming, non-motile cocci (without flagella). The isolate was found to be an aerobic heterotroph capable of utilizing glucose and other simple sugars. Growth was observed between 4 and $25^{\circ} \mathrm{C}$ (optimum, $20^{\circ} \mathrm{C}$ ) and between $\mathrm{pH} 6.0$ and 9.0 (optimum, pH 7.0-7.5). The $\mathrm{G}+\mathrm{C}$ content of the genomic DNA was $61.5 \mathrm{~mol} \%$ and the major quinone was ubiquinone-8. The peptidoglycan of strain $\mathrm{CJ} 2^{\top}$ was determined as belonging to type A1- $\gamma$, meso-diaminopimelic acid. The major fatty acids of strain $\mathrm{CJ} 2^{\top}$ were $16: 1 \omega 7 c(67 \cdot 0 \%)$, $16: 0(19.6 \%), 18: 1 \omega 7 c(\sim 7.9 \%)$ and $10: 03-\mathrm{OH}(\sim 2.5 \%)$. The polar lipids were phosphatidylethanolamine, phosphatidylglycerol and diphosphatidylglycerol. Mycolic acid and glycolipids could not be detected. Comparative $16 \mathrm{~S}$ rDNA analysis indicated that strain $\mathrm{CJ} 2^{\top}$ is related to the family Comamonadaceae and that the nearest phylogenetic relative was Polaromonas vacuolata $34-P^{\top}(97 \cdot 1 \%$ similarity). On the basis of the physiological and molecular properties, the naphthalene-degrading isolate was designated Polaromonas naphthalenivorans $\mathrm{sp}$. nov. The type strain is $\mathrm{CJ} 2^{\top}\left(=\right.$ ATCC BAA $-779^{\top}=$ DSM $\left.15660^{\top}\right)$.
\end{abstract}

Polycyclic aromatic hydrocarbon (PAH) contamination of soil, water or sediment is of concern because PAHs can be toxic and/or carcinogenic. Numerous studies have been conducted on PAH-degrading bacteria, and extensive information has accumulated on the physiology, biochemistry and genetic basis of PAH biodegradation by both Gram-positive and Gram-negative bacteria, especially for pseudomonads, because of their susceptibility to isolation and cultivation (Daane et al., 2001; Fuenmayor et al., 1998; Laurie \& Lloyd-Jones, 1999; Serdar \& Gibson, 1989; Simon et al., 1993).

Coal-tar waste containing high concentrations of PAHs was buried at our study site approximately 40 years ago, contaminating sediments and groundwater in an area $300 \mathrm{~m}$ long by $60 \mathrm{~m}$ wide (Madsen et al., 1991). Although we had

Published online ahead of print on 18 July 2003 as DOI 10.1099/ ijs.0.02636-0.

Abbreviations: MSB agar, minimal salts base agar; $\mathrm{PAH}$, polycyclic aromatic hydrocarbon; $\mathrm{PHA}$, poly- $\beta$-hydroxyalkanoic acid.

The GenBank accession number for the $16 \mathrm{~S}$ rDNA sequence of strain CJ2 ${ }^{\top}$ is AY166684.

Micrographs of strain $\mathrm{CJ} 2^{\top}$, growth curves in various media and details of aromatic hydrocarbon metabolism are available as supplementary material in IJSEM Online. previously isolated a variety of Gram-negative and Grampositive naphthalene-degrading bacteria from the contaminated site (Herrick et al., 1997; Stuart-Keil et al., 1998), a novel Gram-negative bacterium was discovered very recently. Here, we describe this bacterium, strain $\mathrm{CJ} 2^{\mathrm{T}}$, as a novel species designated Polaromonas naphthalenivorans sp. nov.

The biogeochemistry of the study site has been reported previously (Bakermans et al., 2002; Madsen et al., 1991). Samples of surface freshwater sediment, bathed in groundwater flowing through naphthalene-rich coal-tar waste contamination, were diluted serially and spread on minimal salts base (MSB) agar medium (Stanier et al., 1966) incubated in the presence of naphthalene vapour as the sole carbon source at $10^{\circ} \mathrm{C}$ for 1 month. The isolate was routinely grown aerobically at $20^{\circ} \mathrm{C}$ except where indicated otherwise. MSB containing $0 \cdot 2 \%$ pyruvate (w/v), LuriaBertani (LB) broth and oligotrophic medium PYGV (Staley, 1968) were used for growth evaluation of the isolate and related type strains. Broth cultures $(5 \mathrm{ml}$, MSB containing $0.2 \%$ pyruvate) used to inoculate other media were inoculated with a loop of cells and then shaken (200 r.p.m.) overnight. These cells were diluted $1: 20$ for growth assays in other media. Growth was monitored by measuring the $\mathrm{OD}_{600}$. 
Chromosomal DNA was isolated and purified by a method described previously (Cashion et al., 1977). The G+C content was determined by the Deutsche Sammlung von Mikroorganismen und Zellkulturen (DSMZ) using the method of Mesbah \& Whitman (1989). DNA was hydrolysed and the resultant nucleotides were analysed by isocratic reverse-phase HPLC (using Shimadzu equipment).

The morphology of naphthalene-degrading isolate $\mathrm{CJ} 2^{\mathrm{T}}$ was observed using a Zeiss LSM 210 laser scanning microscope equipped for conventional phase-contrast and epifluorescence viewing or a Nikon E600 microscope equipped with differential interference contrast optics. Scanning electron microscopy was done at the Cornell Integrated Microscopy Center. Motility was observed at 12 and $36 \mathrm{~h}$ in wet mounts. Cells were measured and inclusion granules observed in a drop of culture mounted on glass slides coated with $1 \%$ $(\mathrm{w} / \mathrm{v})$ agarose or slides coated with a dried smear of $0.5 \mathrm{mg}$ poly-L-lysine $\mathrm{ml}^{-1}$ (to enhance cellular adhesion). The agarose-coated slides were used to enhance detection of intracellular granules and to make cellular measurements. For scanning electron microscopy, $\mathrm{CJ} 2^{\mathrm{T}}$ was fixed with $3 \%$ glutaraldehyde and $1 \%$ osmium tetroxide and dried with a critical-point dryer using liquid $\mathrm{CO}_{2}$ as the transition fluid. The dried samples were sputter-coated with gold under a vacuum and then examined with a scanning electron microscope (S-4500; Hitachi). The Gram reaction was determined using the Difco Gram Stain kit according to the manufacturer's recommended protocol using light microscopy. Strain $\mathrm{CJ}^{\mathrm{T}}$ was physiologically characterized using API 20E tests (bioMérieux Vitek) as described by Logan \& Berkeley (1984). Other phenotypic tests included those for catalase and oxidase activities and anaerobiosis. The temperature range for growth was determined on MSB solid medium, containing $0.2 \%$ pyruvate, that had been preincubated at the appropriate temperature for $2 \mathrm{~h}$ prior to inoculation. Cells were mounted on Formvar-coated copper grids and negatively stained with $3 \%$ ammonium molybdate or $1 \%$ potassium phosphotungstate broth $(\mathrm{pH} \mathrm{7 \cdot 0)}$. Grids were examined in a Phillips 201 transmission electron microscope operated at $80 \mathrm{kV}$.

Cells grown in MSB-pyruvate broth for $12 \mathrm{~h}$ were fixed onto a glass microscope slide with poly-L-lysine and stained with the Nile pink component of Nile blue A for poly- $\beta$ hydroxyalkanoic acid (PHA) (Ostle \& Holt, 1982; Takeda et al., 2002) and $1 \%$ toluidine blue; this was followed by differentiation with $1 \% \mathrm{H}_{2} \mathrm{SO}_{4}$ for polyphosphate (Murray et al., 1994). In a separate preparation, cells were mounted in Gram's iodine/potassium iodide solution for the detection of polyglucose granules (Stanier et al., 1986). Orange fluorescence observed in the highly refractile granules of the cells under short-wavelength epi-illumination established the presence of PHA in the granules (Takeda et al., 2002). Metachromatic polyphosphate granules and dark blue polyglucose granules were observed under bright-field illumination.

Respiratory lipoquinones were extracted, purified and analysed by the DSMZ using procedures described by Komagata \& Suzuki (1987). The purified lipoquinones were dissolved in acetone and separated by isocratic reverse-phase HPLC by using methanol/isopropanol $(50: 50, \mathrm{v} / \mathrm{v})$ as the eluting solvent. Whole-cell fatty acids were extracted and analysed by GC at the DSMZ and using the Microbial Identification System (MIDI; Microbial ID). The diamino acid of the peptidoglycan was determined by the DSMZ using methods described previously (Komagata \& Suzuki, 1987), and the presence of free mycolic acid was tested according to the method of Tomiyasu \& Yano (1984). The polar lipid profile was determined by the DSMZ using the integrated method for lipid analysis described by Minnikin et al. (1984).

The 16S rDNA was amplified by PCR using two universal primers as described previously (Lane, 1991). PCRs and transformation were conducted according to the modified method of Herrick et al. (1997). Sequencing of both strands of the $16 \mathrm{~S}$ rRNA gene of strain $\mathrm{CJ} 2^{\mathrm{T}}$ was completed on an ABI Prism 377XL instrument (Applied Biosystems). The $16 \mathrm{~S}$ rRNA gene sequences $(\sim 1500 \mathrm{bp})$ of the isolate were assembled using SeqMan (DNASTAR) and compared with available 16S rRNA sequences from GenBank using the BLAST program to determine its approximate phylogenetic affiliation. Sequence-similarity values were computed using DNADIST in PHYLIP version 3.5c (Cole et al., 2003). The $16 \mathrm{~S}$ rDNA sequence of strain $\mathrm{CJ}^{\mathrm{T}}$ was aligned with $16 \mathrm{~S}$ rRNA gene sequences of representatives of related taxa by using CLUSTAL W software (Thompson et al., 1994). Gaps at the $5^{\prime}$ and $3^{\prime}$ ends of the alignment were omitted from further analyses. Construction of phylogenetic trees was computed using two different methods of phylogenetic analysis [parsimony and distance (Kimura two-parameter correction)] available in the PHYLIP software package, version 3.6 (Felsenstein, 2002). The stability of relationships was assessed by using a bootstrap analysis of 1000 datasets through the PHYLIP package.

The procedures described by Daane et al. (2001) were used to assess utilization of a variety of aromatic compounds (naphthalene, phenanthrene, fluorene, pyrene and biphenyl) in MSB liquid medium. Each culture was tested in triplicate for each substrate. Cells were initially grown in $5 \mathrm{ml}$ MSB containing $0 \cdot 2 \%$ pyruvate $(\mathrm{w} / \mathrm{v})$. Each of the test aromatic substrates $(1 \mu$ mole total; dissolved in the volatile solvent hexane) was added to sterile $50 \mathrm{ml}$ serum bottles. After evaporation of the solvent, $10 \mathrm{ml}$ MSB liquid medium was added prior to the addition of $100 \mu \mathrm{l}$ cell inoculum. At time zero, killed controls were prepared by adding $200 \mu \mathrm{l}$ poison $\left(5 \% \mathrm{HCl}, 0.25 \mathrm{M} \mathrm{HgCl}_{2}\right.$ ) to each of the serumbottle treatments. Samples were incubated at $20^{\circ} \mathrm{C}$ for 10 days. At each assay time (0 and 10 days), the serumbottle samples were extracted with $10 \mathrm{ml}$ ethyl acetate and this extract was analysed using a Hewlett Packard 6890 gas chromatograph with an HP-5MS column $(30 \mathrm{~m}, 0 \cdot 25 \mathrm{~mm}$ internal diameter, $0 \cdot 25 \mu \mathrm{m}$ film thickness) and an HP 5973 mass-selective detector. Results are reported as percentages remaining relative to killed controls. 
On MSB-pyruvate and MSB-naphthalene media, strain $\mathrm{CJ} 2^{\mathrm{T}}$ produced circular, convex, beige colonies with smooth and glistening mucoid surfaces. No diffusible pigments were observed. The morphology of strain $\mathrm{CJ} 2^{\mathrm{T}}$ was examined by using scanning electron microscopy and phase-contrast light microscopy (see Supplementary Fig. A in IJSEM Online). The cells were non-motile cocci that varied from 1 to $4 \mu \mathrm{m}$ in diameter. Cells occurred singly or in pairs and often formed small clusters of loosely adherent cells (see Supplementary Fig. A). The cells were Gram-negative and formed large, readily recognizable PHA granules, which fluoresced orange after being stained with Nile pink. Darkblue granules indicative of polyglucose (Stanier et al., 1986) were distributed outside large refractive PHA granules in iodine/potassium iodine-mounted cells. Small metachromatic polyphosphate granules were observed in peripheral regions of cells after toluidine blue staining. These results suggest that strain $\mathrm{CJ} 2^{\mathrm{T}}$ has the unusual ability to store, during exponential growth, all three of the common types of prokaryotic cellular reserve materials (Stanier et al., 1986).

Negatively stained cells were difficult to observe under the transmission electron microscope as they did not readily adhere to the Formvar film. None of the cells observed possessed flagella. Since we did not observe motility in wet mounts of cells at different stages of growth, we assume that $\mathrm{CJ} 2^{\mathrm{T}}$ did not produce flagella under the growth conditions we employed.

Chemical assays of MSB broth supplied with several PAH compounds indicated that, like the two pseudomonad reference strains, strain $\mathrm{CJ}_{2}{ }^{\mathrm{T}}$ metabolized $100 \%$ of the naphthalene provided (Supplementary Table in IJSEM Online). Strain $\mathrm{CJ} 2^{\mathrm{T}}$ was originally recognized by its large $(0.5 \mathrm{~cm})$ mucoid colonies on MSB-naphthalene. In the absence of naphthalene vapour, this growth did not occur. Unlike the naphthalene-degrading reference strains Pseudomonas putida NCIB 9816-4 and Pseudomonas putida $\mathrm{G} 7$, colonies of strain $\mathrm{CJ} 2^{\mathrm{T}}$ failed to produce an obvious zone of clearing when sprayed with an ethereal solution of phenanthrene as described by Kiyohara et al. (1982). Strain $\mathrm{CJ}^{\mathrm{T}}$ was found to be an aerobic heterotroph capable of utilizing glucose and other simple sugars. Growth in MSBnaphthalene and MSB-pyruvate agar media was observed between 4 and $25^{\circ} \mathrm{C}$, and the optimum temperature was about $20^{\circ} \mathrm{C}$. However, growth was not detectable at $30^{\circ} \mathrm{C}$. The optimum $\mathrm{pH}$ of strain $\mathrm{CJ} 2^{\mathrm{T}}$ on MSB containing $0 \cdot 2 \%$ pyruvate was about $7 \cdot 0-7 \cdot 5$. The bacterium was oxidaseand catalase-positive. Its growth rate was markedly diminished in rich (100\% and $20 \% \mathrm{LB}$ ) media, relative to MSB-pyruvate and oligotrophic PYGV media (Staley, 1968) (Supplementary Fig. B). Gelatinase and citrate-utilization tests were positive. Arginine was hydrolysed by strain $\mathrm{CJ} 22^{\mathrm{T}}$ but ONPG was not. Strain $\mathrm{CJ} 2^{\mathrm{T}}$ did not produce lysine decarboxylase, ornithine decarboxylase, tryptophan deaminase, urease, hydrogen sulfide, indole or acetoin and also did not produce acid from D-glucose, mannitol, sucrose or arabinose. Growth was not significant on MSB-glucose plates incubated anaerobically; furthermore, anaerobic growth on this medium was not enhanced by added sodium nitrate.

Strain $\mathrm{CJ}^{\mathrm{T}}$ grows readily on MSB agar with naphthalene vapour as the sole source of carbon and energy at $10^{\circ} \mathrm{C}$. At temperatures above $20^{\circ} \mathrm{C}$, growth does not occur, possibly because the vapour pressure of naphthalene is toxic. At $20^{\circ} \mathrm{C}$, growth of strain $\mathrm{CJ}^{\mathrm{T}}$ on naphthalene vapour is not robust and may be influenced by the presence of capsular material, which may mitigate toxicity. Strain $\mathrm{CJ} 2^{\mathrm{T}}$ does not grow in MSB broth with naphthalene crystals in the medium.

The major quinone found in the strain $\mathrm{CJ}^{\mathrm{T}}$ was ubiquinone-8. The fatty acid profile of strain $\mathrm{CJ} 2^{\mathrm{T}}$ was characterized by the presence of $16: 1 \omega 7 c(67 \cdot 0 \%), 16: 0$ $(19 \cdot 6 \%), 18: 1 \omega 7 c(\sim 7 \cdot 9 \%)$ and $10: 03-\mathrm{OH}(\sim 2 \cdot 5 \%)$. The fatty acid profile did not match any in the MIDI identification system. The $\mathrm{G}+\mathrm{C}$ content of strain $\mathrm{CJ} 2^{\mathrm{T}}$ was $61.5 \mathrm{~mol} \%$. The major peptidoglycan of strain $\mathrm{CJ} 2^{\mathrm{T}}$ was determined as belonging to type A1- $\gamma$, meso-diaminopimelic acid. The polar lipids were phosphatidylethanolamine, phosphatidylglycerol and diphosphatidylglycerol. Neither mycolic acid nor glycolipids could be detected in cells of strain $\mathrm{CJ} 22^{\mathrm{T}}$. The fatty acid composition and the lipoquinone are typical of the $\beta$-Proteobacteria.

Phylogenetic analysis of the 16S rDNA sequence showed that strain $\mathrm{CJ} 2^{\mathrm{T}}$ was closely related to members of the family

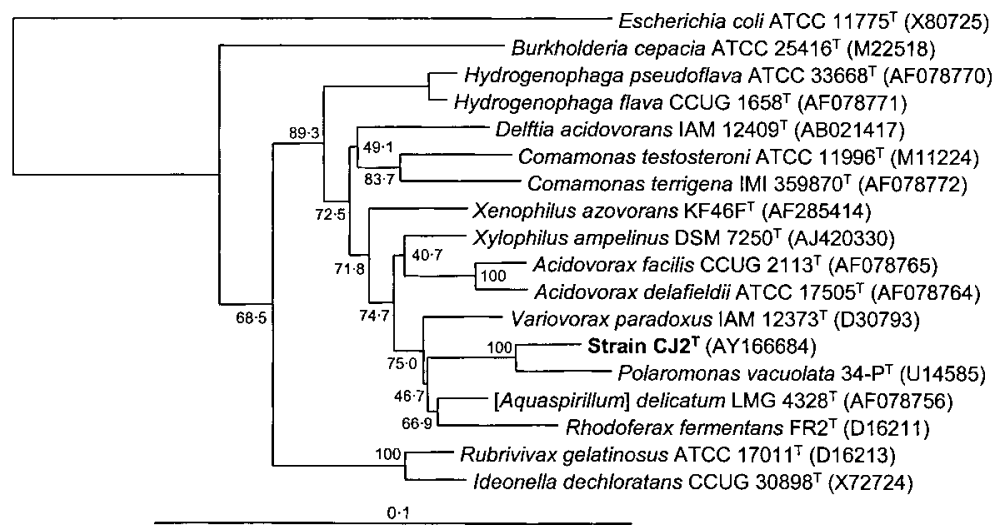

Fig. 1. Phylogenetic position of strain $\mathrm{CJ}^{\top}$ among related bacteria. The tree was produced using the neighbour-joining algorithm and was calculated using $\sim 1500$ bases of the 16S rRNA gene. Escherichia coli was used as an outgroup. The scale bar represents $0 \cdot 1$ changes per nucleotide position. 


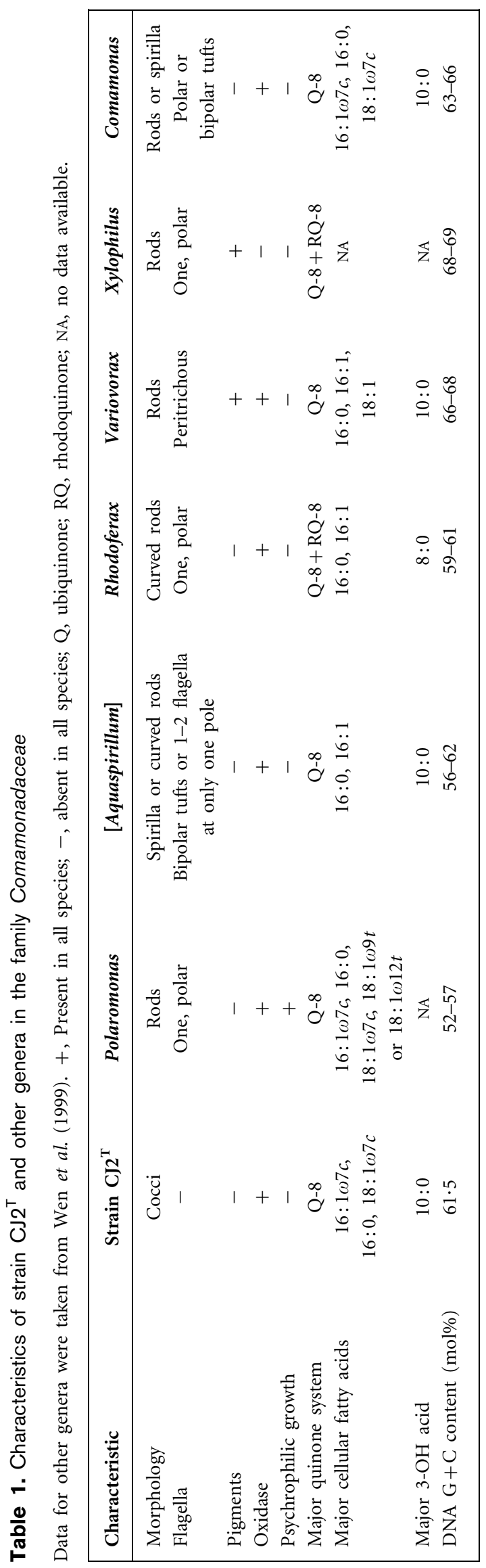

Comamonadaceae (Fig. 1). The nearest known relatives of strain $\mathrm{CJ}_{2}{ }^{\mathrm{T}}$ were Polaromonas vacuolata $34-\mathrm{P}^{\mathrm{T}}(97 \cdot 1 \%$ similarity), Aquaspirillum delicatum LMG 4328 (95.1\%) and Variovorax paradoxus IAM $12373^{\mathrm{T}}(94 \cdot 2 \%)$. Table 1 features several phenotypic traits of strain $\mathrm{CJ} 2^{\mathrm{T}}$ that can differentiate it from phylogenetically related strains of the family Comamonadaceae of the $\beta$-Proteobacteria (Wen et al., 1999). Two other phenotypic features that distinguish strain $\mathrm{CJ} 2^{\mathrm{T}}$ from all other strains of the Comamonadaceae are its coccoid and unflagellated (non-motile) morphology. The closest known relative of $\mathrm{CJ} 2^{\mathrm{T}}$ clearly is Polaromonas vacuolata $34-\mathrm{P}^{\mathrm{T}}$, especially with regard to $16 \mathrm{~S} \mathrm{rDNA}$ sequence and major cellular fatty acids; however, the latter shows growth at lower temperatures, a lower $\mathrm{G}+\mathrm{C}$ content, flagellation and rod-shaped cells (Irgens et al., 1996). On the basis of its distinctive physiological, morphological and other key traits, it is proposed that strain $\mathrm{CJ} 2{ }^{\mathrm{T}}$ represents a novel species, for which the name Polaromonas naphthalenivorans sp. nov. is proposed.

\section{Description of Polaromonas naphthalenivorans sp. nov.}

Polaromonas naphthalenivorans (naph.thal.en.i.vo'rans. N.L. neut. n. naphthalenum naphthalene; L. part. adj. vorans consuming; N.L. neut. adj. naphthalenivorans naphthalene-consuming).

Cells are non-motile, presumably non-flagellated, Gramnegative, aerobic cocci of variable size $(1-4 \mu \mathrm{m})$, usually found individually or in small clusters of loosely adherent cells. Oxidase- and catalase-positive. The optimum growth temperature and $\mathrm{pH}$ are respectively $20^{\circ} \mathrm{C}$ and $7-7 \cdot 5$. Many simple sugars are utilized. PHA, polyglucose and polyphosphate granules accumulate as storage material. Chemo-organotrophic. The $\mathrm{G}+\mathrm{C}$ content is approximately $61.5 \mathrm{~mol} \%$ and ubiquinone- 8 is the major quinone. Cells form circular, convex colonies with smooth and glistening surfaces. Pigment is not produced. Growth is not observed at $30^{\circ} \mathrm{C}$. The growth rate is much lower in $\mathrm{LB}$ medium than in MSB or oligotrophic media. Large $(0.5 \mathrm{~cm})$ mucoid colonies are produced with naphthalene vapour as the carbon-source medium at $10^{\circ} \mathrm{C}$. Naphthalene is efficiently removed from solution. Tests for gelatinase, citrate utilization and arginine hydrolase are positive. ONPG is not hydrolysed. Assays for lysine decarboxylase, ornithine decarboxylase, tryptophan deaminase and urease are negative. Hydrogen sulfide, indole and acetoin are not produced. Acid, but no gas, is produced from D-glucose, mannitol, sucrose and arabinose. The major cellular fatty acids are $16: 1 \omega 7 c(67 \cdot 0 \%), 16: 0(19 \cdot 6 \%), 18: 1 \omega 7 c(\sim 7 \cdot 9 \%)$ and 10:0 3-OH $(\sim 2.5 \%)$. The major peptidoglycan is type A1- $\gamma$, meso-diaminopimelic acid. The polar lipids are phosphatidylethanolamine, phosphatidylglycerol and diphosphatidylglycerol. Mycolic acid and glycolipids are not detected.

The type strain is $\mathrm{CJ} 2^{\mathrm{T}} \quad\left(=\mathrm{ATCC} \quad \mathrm{BAA}-779^{\mathrm{T}}=\mathrm{DSM}\right.$ $\left.15660^{\mathrm{T}}\right)$, which was isolated from coal-tar-contaminated surface sediments from South Glens Falls, NY, USA. 


\section{Acknowledgements}

This research was supported by NSF grant MCB-0084175 and by the postdoctoral fellowships programme of the Korea Science Engineering Foundation (KOSEF).

\section{References}

Bakermans, C., Hohnstock-Ashe, A. M., Padmanabhan, S. Padmanabhan, P. \& Madsen, E. L. (2002). Geochemical and physiological evidence for mixed aerobic and anaerobic field biodegradation of coal tar waste by subsurface microbial communities. Microb Ecol 44, 107-117.

Cashion, P., Holder-Franklin, M. A., McCully, J. \& Franklin, M. (1977). A rapid method for the base ratio determination of bacterial DNA. Anal Biochem 81, 461-466.

Cole, J. R., Chai, B., Marsh, T. L. \& 8 other authors (2003). The Ribosomal Database Project (RDP-II): previewing a new autoaligner that allows regular updates and the new prokaryotic taxonomy. Nucleic Acids Res 31, 442-443.

Daane, L. L., Harjono, I., Zylstra, G. J. \& Haggblom, M. M. (2001). Isolation and characterization of polycyclic aromatic hydrocarbondegrading bacteria associated with the rhizosphere of salt marsh plants. Appl Environ Microbiol 67, 2683-2691.

Felsenstein, J. (2002). PHYLIP (phylogeny inference package), version 3.6a. University of Washington, Seattle, USA.

Fuenmayor, S. L., Wild, M., Boyes, A. L. \& Williams, P. A. (1998). A gene cluster encoding steps in conversion of naphthalene to gentisate in Pseudomonas sp. strain U2. J Bacteriol 180, 2522-2530.

Herrick, J. B., Stuart-Keil, K. G., Ghiorse, W. C. \& Madsen, E. L. (1997). Natural horizontal transfer of a naphthalene dioxygenase gene between bacteria native to a coal tar-contaminated field site. Appl Environ Microbiol 63, 2330-2337.

Irgens, R. L., Gosink, J. J. \& Staley, J. T. (1996). Polaromonas vacuolata gen. nov., sp. nov., a psychrophilic, marine, gas vacuolate bacterium from Antarctica. Int J Syst Bacteriol 46, 822-826.

Kiyohara, H., Nagao, K., Kouno, K. \& Yano, K. (1982). Phenanthrenedegrading phenotype of Alcaligenes faecalis AFK2. Appl Environ Microbiol 43, 458-461.

Komagata, K. \& Suzuki, K. (1987). Lipid and cell-wall analysis in bacterial systematics. Methods Microbiol 19, 161-208.

Lane, D. J. (1991). 16S/23S rRNA sequencing. In Nucleic Acid Techniques in Bacterial Systematics, pp. 115-147. Edited by E. Stackebrandt \& M. Goodfellow. New York: Wiley.

Laurie, A. D. \& Lloyd-Jones, G. (1999). The phn genes of Burkholderia sp. strain RP007 constitute a divergent gene cluster for polycyclic aromatic hydrocarbon catabolism. J Bacteriol 181, 531-540.

Logan, N. A. \& Berkeley, R. C. W. (1984). Identification of Bacillus strains using the API system. J Gen Microbiol 130, 1871-1882.
Madsen, E. L., Sinclair, J. L. \& Ghiorse, W. C. (1991). In situ biodegradation: microbiological patterns in a contaminated aquifer. Science 252, 830-833.

Mesbah, M. \& Whitman, W. B. (1989). Measurement of deoxyguanosine/thymidine ratios in complex mixtures by high-performance liquid chromatography for determination of the mole percentage guanine + cytosine of DNA. J Chromatogr 479, 297-306.

Minnikin, D. E., Minnikin, S. M., O’Donnell, A. G. \& Goodfellow, M. (1984). Extraction of mycobacterial mycolic acids and other-longchain compounds by an alkaline methanolysis procedure. J Microbiol Methods 2, 243-249.

Murray, R. G. E., Doetsch, R. N. \& Robinow, C. F. (1994). Determination and cytological light microscopy. In Methods for General and Molecular Bacteriology, pp. 21-41. Edited by P. Gerhardt, R. G. E. Murray, W. A. Wood \& N. R. Krieg. Washington, DC: American Society for Microbiology.

Ostle, A. G. \& Holt, J. G. (1982). Nile blue A as a fluorescent stain for poly-beta-hydroxybutyrate. Appl Environ Microbiol 44, 238-241.

Serdar, C. M. \& Gibson, D. T. (1989). Studies of nucleotide sequence homology between naphthalene-utilizing strains of bacteria. Biochem Biophys Res Commun 164, 772-779.

Simon, M. J., Osslund, T. D., Saunders, R. \& 7 other authors (1993). Sequences of genes encoding naphthalene dioxygenase in Pseudomonas putida strains G7 and NCIB 9816-4. Gene 127, 31-37.

Staley, J. T. (1968). Prosthecomicrobium and Ancalomicrobium: new prosthecate freshwater bacteria. J Bacteriol 95, 1921-1942.

Stanier, R. Y., Palleroni, N. J. \& Doudoroff, M. (1966). The aerobic pseudomonads: a taxonomic study. J Gen Microbiol 43, 159-271.

Stanier, R. Y., Ingraham, J. L., Wheelis, M. L. \& Painter, P. R. (1986). The Microbial World, 5th edn. Englewood Cliffs, NJ: Prentice Hall.

Stuart-Keil, K. G., Hohnstock, A. M., Drees, K. P., Herrick, J. B. \& Madsen, E. L. (1998). Plasmids responsible for horizontal transfer of naphthalene catabolism genes between bacteria at a coal tarcontaminated site are homologous to pDTG1 from Pseudomonas putida NCIB 9816-4. Appl Environ Microbiol 64, 3633-3640.

Takeda, M., Kamagata, Y., Ghiorse, W. C., Hanada, S. \& Koizumi, J. (2002). Caldimonas manganoxidans gen. nov., sp. nov., a poly(3hydroxybutyrate)-degrading, manganese-oxidizing thermophile. Int J Syst Evol Microbiol 52, 895-900.

Thompson, J. D., Higgins, D. G. \& Gibson, T. J. (1994). CLUSTAL W: improving the sensitivity of progressive multiple sequence alignment through sequence weighting, position-specific gap penalties and weight matrix choice. Nucleic Acids Res 22, 4673-4680.

Tomiyasu, I. \& Yano, I. (1984). Separation and analysis of novel polyunsaturated mycolic acids from a psychrophilic, acid-fast bacterium, Gordona aurantiaca. Eur J Biochem 139, 173-180.

Wen, A., Fegan, M., Hayward, C., Chakraborty, S. \& Sly, L. I. (1999). Phylogenetic relationships among members of the Comamonadaceae, and description of Delftia acidovorans (den Dooren de Jong 1926 and Tamaoka et al. 1987) gen. nov., comb. nov. Int J Syst Bacteriol 49, 567-576. 